\title{
HitchHiking AND Missing AND MuR- DERED INDIGENOUS WOMEN: A CRITICAL Discourse ANALYsis of Billboards on THE Highway OF Tears
}

KATHERINE MORTON

\begin{abstract}
Whether too much or the wrong kind, constraining Indigenous mobility is a preoccupation of the province of British Columbia. The province remains focussed on controlling Indigenous mobility and constructing forms of contentious mobility, such as hitchhiking, as bad or risky. In Northwestern British Columbia hitchhiking is particularly common among Indigenous women. Hitchhiking as a mode of contentious mobility is categorically named as "bad mobility" and is frequently explained away as risky behaviour. Mobility of Indigenous women, including hitchhiking is deeply gendered and racialized. The frequent description of missing and murdered Indigenous women as hitchhikers or drifters fosters a sense that "choosing" a bad mode of mobility alone is the reason that these women disappear. This paper will identify how hitchhiking, framed as contentious mobility, supports the construction of missing and murdered Indigenous women as willing, available and blame-worthy victims. Morality is tangled up with mobility in the province's responses to Indigenous women who hitchhike. This paper engages in a critical discourse analysis of billboards posted by the province of British Columbia along the Highway of Tears that attempt to prevent women from hitchhiking. This paper will identify the point of convergence between contentious mobility, violence against Indigenous women and larger questions of colonialism and the negotiation of racialized and gendered power imbalances through the province's constraining of Indigenous mobility.
\end{abstract}

Keywords: Hitchhiking, colonization, intersectionality, billboards, missing and murdered Indigenous women, violence, gender, Highway of Tears

Résumé. Excessives ou mal ciblées, les tentatives visant à restreindre la mobilité des Autochtones dans la province de Colombie-Britannique sont une source de préoccupation. La province s'efforce à contrôler la mobilité des Autochtones et à présenter les formes de mobilité controversées, tel l'auto-stop, comme des pratiques indésirables ou risquées. Au Nord-Ouest de la Colombie-Britannique, l'auto-stop est une pratique tout particulièrement courante chez les femmes au- 
tochtones. L'auto-stop en tant que mode de mobilité controversé est désigné comme " mobilité indésirable » et est fréquemment considéré comme un comportement à risque. La mobilité des femmes autochtones, incluant la pratique de l'auto-stop, a une dimension profondément sexuée et ethnique. La description fréquente de femmes autochtones enlevées ou assassinées comme étant des autostoppeuses ou des fugueuses alimente une perception selon laquelle le « choix » d'un mode de transport risqué est l'unique raison pour laquelle ces femmes ont disparu. Cet article discute de comment le fait de présenter la pratique de l'auto-stop comme un moyen de transport à haut risque encourage la perception des femmes autochtones enlevées ou assassinées comme des victimes consentantes et responsables de leur sort. La réponse de la province aux femmes autochtones pratiquant l'auto-stop est un discours sur la mobilité présenté sur un ton moralisateur. Cet article présente une analyse critique du discours des panneaux affichés par la province de la Colombie-Britannique le long de la route des pleurs qui tentent de dissuader les femmes de faire de l'auto-stop. Cet article détermine le point de convergence entre la mobilité controversée, la violence faite aux femmes autochtones et des questions plus vastes sur le colonialisme et la négociation du déséquilibre des pouvoirs liés à l'ethnie et au sexe par le biais de la contrainte de la province sur la mobilité des autochtones.

Mots clés: Auto-stop, colonisation, intersectionnalité, panneaux, femmes autochtones assassinées ou enlevées, violence, genre, route des pleurs

\section{INTRODUCTION}

His ghway 16 in Northwestern British Columbia is named The Highway of Tears for the substantial (although uncertain) number of Indigenous women who have disappeared. This remote and underserviced highway is a critical case of violence against Indigenous women, with the relationship between mobility, space, gender and race being embodied in the acts of violence perpetrated against Indigenous women. The intersection of race, gender, mobility and violence is central to the numerous cases of missing and murdered Indigenous women and demonstrates the importance of not treating mobility as neutral, but seeing it as political and unequal.

The primary mode of mobility used by women who have disappeared along the Highway of Tears is hitchhiking (Sethi 2007). The Royal Canadian Mounted Police (RCMP) in conjunction with the municipal, provincial and federal levels of government have implemented a campaign against hitchhiking on this highway. One of the major apparatuses used in this effort is the publication of large roadside billboards that indicate the dangers of hitchhiking (Images 1 and 2). The response by the province is one of targeting the behaviour of Indigenous women who 
hitchhike. Through a critical discourse analysis of the billboards along the Highway of Tears, I identify the messages used by the province that target Indigenous women and attempt to construct hitchhiking as a contentious form of mobility.

\section{Defining Contentious Mobility}

The term contentious mobility describes modes of mobility that are counter to the dominant mode of automobility and are stigmatized or treated as undesirable. Contentious mobility takes place outside of the moral and physical boundaries of mainstream society. Hitchhiking's status as contentious is however not a constant. At various points in history and across different societies, hitchhiking was and is seen as a desirable and advantageous mode of transportation, even where alternatives exist.

Hitchhiking is a form of contentious mobility because it functions in a different way than the independence of automobility, where the car-driver is in the ultimate position of personal autonomy in regards to where they travel, how fast and to what end. Hitchhiking, although utilizing vehicles, places the hitchhiker in the position of being a resource (mobility) sharer with the vehicle's driver. This interdependence of hitchhiking is what sets it apart from the dominant mode of automobility and also makes hitchhiking potentially dangerous. Hitchhikers, by the very nature of hitching, are dependent on drivers, including strangers. Hitchhiking in the contemporary setting has a reputation as being dangerous and undesirable as a mode of mobility. It is seen as a mode of last resort. In Northwestern British Columbia, hitchhiking is common, but also stigmatized for being dangerous and socially unacceptable. Current unacceptability of hitchhiking is intrinsically connected to race in the construction of missing and murdered Indigenous women and also in the construction of the space of the Highway of Tears. Regardless of whether or not hitchhiking is as dangerous as it is portrayed to be, it is caught up into a web of race and gender that creates the narrative of risky behaviour and violence against Indigenous women.

I am not seeking to make a definitive statement on the safety or risk of hitchhiking, but instead I argue that the billboards along the Highway of Tears demonstrate a concerted effort to present hitchhiking as wrong and dangerous. To conceptualize hitchhiking as a mode of contentious mobility, the new mobilities paradigm is used for analysis (Urry 2007; Sheller and Urry 2006). The mobility paradigm introduces a shift in social inquiry towards considering movement (of people, ideas and goods) 
as worthy of analysis in and of itself. Within the mobility paradigm, automobility or the system of mobility and associated social structures related to cars is central (Featherstone, Thrift \& Urry 2005). Sheller and Urry argue that not having a personal vehicle makes individuals susceptible to disenfranchisement and social exclusion (2000: 739). Sheller and Urry's analysis of automobility is important in understanding hitchhiking as reactionary and contentious within the dominance of automobility (2006: 208). As the following sections present, the Highway of Tears provides an evocative space of intersection between the dominance of automobility, and race/ gender constructs of Indigenous women who hitchhike.

\section{The Highway of Tears}

Razack notes that over a quarter of the missing and murdered Indigenous women disappeared in British Columbia (2015: 54). Razack links this statistic to disappearances centralized in Vancouver's Downtown Eastside and to the Highway of Tears (2015: 54). There are a number of specific characteristics of the Highway of Tears that increase the use of hitchhiking along this route. One such characteristic is the remoteness of the highway (Sethi 2007). The Highway of Tears covers an enormous area of undeveloped wilderness or sparsely populated communities. The highway is both an essential lifeline to connect these communities and is also underserviced. In order to move along the highway, a car is essential. Bus service along the highway is lacking and many individuals are faced with financial barriers to accessing bus service (Sethi 2007). There are few rest areas, shelters or emergency services for hitchhikers and other travelers to access between communities. Cell phone reception, although improved, is still inconsistent. These coverage gaps make it difficult for anyone on the highway to maintain contact with others or to call for help if an emergency takes place (Sethi 2007: 60). Once an individual goes missing, the natural terrain of the region also presents an obstacle for search efforts. The region's heavy forest coverage prevents extensive searches and often slows down the efforts to locate valuable information and evidence.

\section{Diversity in Experiences of MobiLity}

Hitchhiking is not universally safe or unsafe, just as can be said for all forms of mobility. Furthermore, it is essential to recognize that the experiences of Indigenous women who live in the communities along 
the Highway of Tears, move along the highway or are missing or murdered along the highway are also diverse and complicated. Indigenous women's experiences with mobility and with violence cross all socioeconomic and social divisions and it is inaccurate to treat Indigenous women as victims in waiting or as all being impacted by the Highway of Tears in the same way. Without being caught in a trap of essentializing experience, it is clear that something deeply problematic with regard to the intersection of race, gender and mobility is resulting in a high number of female Indigenous hitchhikers facing violence.

Indigenous is used as an imperfect but workable label for this research. In many cases of missing and murdered women, the issue of identity is complicated and disappeared women have been identified as First Nations, Inuit, Métis, non-status or any combination of these identities being used by relatives, official reports, the RCMP and the media. As a result, Indigenous is used throughout this paper in an attempt to encompass the complexity of a multiplicity of identities. References will be made later in this paper to the Indian Act as a mechanism for constraining mobility and it is recognized that this Act was not applicable to all people of Indigenous descent/identity. However, in an effort to find inclusive language in cases where identity is exceedingly complex and connected to the ongoing impacts of colonization, Indigenous was selected.

\section{Colonization Literature Review}

Colonization is the historical frame through which all contemporary violence against Indigenous peoples must be analyzed. Colonization has continued to have devastating social consequences for Indigenous peoples such as high rates of poverty, overrepresentation in the corrections system, child welfare issues, educational inequalities and high unemployment (Razack 2002; Thobani 2007). I echo Razack's claim that, "the twelve hundred missing Indigenous women, some of whom are presumed murdered, can be connected historically to the Indigenous women whom settlers, colonial police, and officials considered sexually available and expendable" (2015: 22).

According to colonial and patriarchal ideologies, Indigenous women are positioned outside of the conventional boundaries of privileged femininity (Gilchrist 2010; Jiwani 2009; Culhane 2003; England 2000). As colonized people, their gender and racial identity intersects to marginalize and remove Indigenous women from dominant society (Bannerji 1993; Dhamoon 2009; Dobrowolsky and Jensen 2004; Fiske 2006). 
Indigenous women are subjected to the damaging "squaw" stereotype (Jiwani 2009; Jiwani and Young 2006; Razack 2002). This stereotype frames Indigenous women as promiscuous, prone to deviance and incapable of controlling impulses (Jiwani 2009). As McClintock and hooks have both argued, whiteness is rendered invisible by becoming raceless; it becomes an "invisible norm" (McClintock 1995; hooks 2000). Grande indicates that in the discourse of Indigenous issues, there is a position of "whiteness as a significant marker of racial, class, and gender privilege" (2004: 6). The construction of whiteness functions within the dichotomy developed by LaRoque of civilization and savagery (1983: 86). LaRoque argues that, "[t]he Whiteman's belief in "civilization" and its antithesis "savagery" was perhaps the most central and certainly the most persistent idea throughout the centuries" (1983: 86). The privileged position of white members of Canadian society made them the exclusive keepers of civilization, while the colonized Indigenous populations, as the antithesis to whiteness, were considered savage, backwards and primitive (LaRoque 1986).

Many women living along the Highway experience poverty, unemployment and inadequate education opportunities, leading to social marginalization and increased risk of violence (Sethi 2007). Gendered and racialized stereotypes further exacerbate this exclusion by rendering Indigenous women as contrary to the dominant social order and therefore a threat (Razack 2002). Indigenous women are constructed as "willing victims" who deserve the violence they face because of their "lifestyle choices" (Comack and Balfour 2004). Race is one element that Comack and Balfour indicate impacts both the culpability of the defendant and the innocence of the victim (2004: 108). Gilchrist echoes this idea by arguing that "if a victim is judged to have deviated from patriarchal notions of appropriate feminine behaviour....she is likely to be constructed as, at least partially responsible for violence against her" (2010: 376). One way in which missing and murdered Indigenous women appear to "deviate from patriarchal notions of appropriate feminine behaviour" (Gilchrist 2010: 376) is through the contentious mobility of hitchhiking. Blame is implicitly assigned to Indigenous women as a result of prejudicial constructions of Indigenous femininity. Hitchhiking frames Indigenous women as wrong-doers, and in doing so conflates their morality with their mobility. 


\section{Technologies of Mobility and Politics of Exclusion}

Technologies of mobility vary according to socio-economic factors such as the availability of the technology and the financial position of the mobile person (Sheller and Urry 2006; Urry 2007; Thrift 2004). The income of Indigenous women is often well below that of their non-Indigenous counterparts resulting from their social marginalization (Moores 2006; Pratt 2005; McGrath and Stevenson 1996). Indigenous women frequently move along the highway in order to access social services including women's shelters, employment services, health services and education (Culhane 2004: 601).

Thobani looks at the construction of the "Indian" through Agamben's concepts of homo sacer and zoe (2007: 39). Agamben defines the homo sacer as excepted bodies who can be killed with impunity but not sacrificed and are tied to the social order in so far as they are excluded from it. Alternatively, zoe, as Agamben describes it, is a state devoid of any access to the good/ qualified life. They are dehumanized to a point of being simply natural impulse and they are depoliticized to the most extreme degree. Indigenous peoples, "[e]mptied of their politico-human status by the legal regimes of the colonizers" occupy the liminal space between these two figures (Thobani 2007: 39). Thobani engages with Agamben in order to explain Canada's treatment (and validation of their treatment) of Indigenous peoples (2007: 40). By locating Indigenous peoples within a state of exception, any violence is rendered inconsequential.

Bauman notes the "order-building" processes of maintaining and legitimizing the nation-state are always a process of selective belonging (production) and exclusion (waste) (2004: 40). Bauman argues that, "the nation-state has claimed the right to preside over the distinction between order and chaos, law and lawlessness, citizen and homo sacer, belonging and exclusion" (Bauman 2004: 33). Bauman terms these excluded bodies "wasted lives" (2004: 5). Wasted lives have no productive purpose within society and are treated as resource drains and chaos to be managed (Bauman 2004). Bauman's analysis of wasted lives rings true to the social marginalization of Indigenous people in Canada. Indigenous female hitchhikers, by moving outside of the borders of dominant society fall within the social category of wasted lives.

Wacquaint develops a similar idea in relation to how ghettos extricate the undesirable low-income African American population from the privileged white population (2001: 102). Like Bauman's description of wasted lives as the useless refuse of modern society, a ghetto acts as "a human warehouse wherein are discarded those segments of urban society deemed disreputable, derelict, and dangerous" (Wacquaint 2001: 
103). This casting out of racialized undesirables is similar to the Canadian context, where Indigenous peoples are constructed as "disreputable, derelict and dangerous" (Wacquaint 2001: 103). The African American and Indigenous populations of the U.S. and Canada respectively are treated as threats to be contained by creating specific zones of exclusion, demonizing mobility and perpetuating racist stereotypes. The colonization of Indigenous peoples was the central process through which the distinction between order and chaos was determined in Canada. The creation of the racialized boundary between the productive, law-abiding and privileged Canadian citizen and the criminal, deviant and destructive Indigenous body was central in the development of the Canadian nationstate (Thobani 2007: 74).

Cacho frames her argument similarly in regards to how Indigenous peoples and other racialized groups are subject to exception and expulsion from society (2012: 7). She argues, "[r]acism is a practice of abstraction. It creates spaces of living death and populations "dead-toothers"' (Cacho 2012: 7). The criminalization of Indigenous bodies and the stigmatization of "lifestyle choices" that Indigenous people are perceived to make are also spatialized. The Highway of Tears is racialized as a site of contentious Indigenous mobility, transiency and other high risk behaviours (Sethi 2007). The racialization of spaces sets up a certain perception of crimes and violence that take place within them. Comack and Balfour argue that, "racialized spaces set the context in which the actions of complainants and witnesses are reduced to "lifestyle choices" (2004: 108). Along the Highway of Tears, violence defines boundaries of inclusion and exclusion, personhood and exception, colonizer and colonized.

\section{Race, Gender, Class and Mobility}

Historic constraints on Indigenous mobility are often left out of analyses of contemporary contentious mobility of Indigenous peoples such as hitchhiking. The absence of the causal link between colonization, the residential schools program, land seizures and displacement with contemporary mobility issues for Indigenous people diminishes the ongoing role of colonization. Comack and Balfour comment that, "the historical colonization and displacement of Aboriginal people on to isolated and impoverished spaces is simply translated into a problem of Aboriginal peoples" (2004: 92).

Kelm notes that the social and health problems conventionally associated with Indigenous peoples (including obesity, mental illness, 
substance abuse and alcoholism) were blamed on Indigenous women as failed mothers and caretakers (1998: 149). Colonial constructions of Indigenous bodies as dirty/diseased were connected to larger sexist/racist narratives of Indigenous women as unfit mothers who were not hygienic themselves and therefore produced dirty/diseased families (1998: 149). Indigenous women are also stereotyped as vectors of contagion for sexually transmitted infections and diseases (Kelm 1998: 149). This conflation between Indigenous women and infection represents both the racist stereotype that Indigenous peoples are unclean and also the racist/sexist stereotype that Indigenous women are sexually deviant and promiscuous (Kelm 1998). Constraining the mobility of Indigenous women, became an issue of public health and safety for the privileged non-Indigenous society (Mawani 2002). In order to control the perceived infectious risk of contact with Indigenous women, the government engaged in actions to constrain mobility such as the pass system housed within the Indian Act. Granted, the Indian Act is only applicable to a portion of the total Indigenous population, but this Act demonstrates a critical example of racialized constraining of mobility.

The provisions of the Indian Act have dictated the racist/sexist approach of the Canadian government and its agencies towards Indigenous peoples. The Indian Act had considerable impacts on Indigenous mobility, especially in the Act's provisions to shape the "confinement of natives to reserves" (Razack 2015: 15). Although the Indian Act was only designed to be applicable to status Indians First Nations), the constraints on Indigenous mobility also impacted other Indigenous peoples as well. The Indian Act and the reserve system constrained mobility and distanced Indigenous bodies from defined settler-colonial spaces such as cities (Razack 2002: 135). As confining First Nations peoples to reserves was desirable for the Canadian state, any form of mobility outside of the allotted movement to and from reserves became contentious. Hitchhiking is a contentious form of mobility as it contravenes the privileged mode of independent driver automobility. It is further rendered contentious when it is used by Indigenous women as a result of the intersections between race, class, gender and mobility.

\section{Method}

This paper uses Norman Fairclough's three-dimensional approach to critical discourse analysis (1989). In this form of critical discourse analysis, text is analyzed at the micro, mezzo and macro level (Fairclough, 1989). The micro level analysis consists of an in-depth analysis of the 
text including word choice, the use of metaphors, the sentence structure and other language choices. The mezzo level of analysis considers how the discourse is presented/published and how it is consumed (Fairclough 1989). An example of mezzo analysis is analyzing the medium of billboards and how they are presented and consumed by an audience. Finally, the macro level of critical discourse analysis examines how the particular text functions within socio-cultural practices (Fairclough 1989). By following this three dimensional approach, this paper will analyze the content of the billboards (both the written words and the imagery used), consider the use of billboards and the implications of this medium and finally situate these billboards within their socio-cultural context in contemporary Northwestern British Columbia.

For this research, an analysis was completed of the images, text and arrangement of material on billboards that were posted through the combined efforts of municipal, provincial and federal governments and also the RCMP. The billboards are located along the Highway of Tears and are updated on the basis of need and funding. For the purposes of this project, the published billboards visible between November 2015 and January 2016 were used. The reason the billboards were selected as material for analysis was because they were highly visible and public presentations of the province's attitude towards hitchhiking as a contentious mode of mobility and were specifically designed as a provincial response to the large number of instances of missing and murdered Indigenous women along the Highway of Tears. The billboards were also chosen in that they were easily accessible and it was possible to get a sense of consistency in the province's messaging across all of the published billboards. The discourse analysis was qualitative and included an analysis of the word choice used in the headline, subsequent text and any names used on the signs. It also included a rudimentary visual discourse analysis of the imagery used on the billboards and also a qualitative analysis of the overall tone of the messaging of the billboard. Key themes that were measured include specific naming of hitchhiking, how the audience was targeted, and how the signage presented missing and murdered Indigenous women. The content was then synthesized and arranged into major themes and narratives. Those findings will be presented in the subsequent sections of this paper.

\section{Billboard Analysis}

Two major billboards are present along the Highway of Tears that are government-funded (Images 1 and 2). The language of each billboard 
was assessed independently and then later compared in an effort to trace similarities. The first billboard I analyzed for this paper is co-sponsored by the regional district of Kitimat-Stikine, the Gitxkan First Nation and the province of British Columbia (Image 1). This same billboard design was reproduced and is located at two points along the highway: Gitwangak and Thornhill. At the time of research, there were three known copies of the same billboard along the highway. The second billboard that is covered in this paper is also co-sponsored by province of British Columbia, but in association with the Aboriginal Women's Action Network. This billboard is positioned near Moricetown, a First Nation's community near the regional centre of Smithers. The billboards analyzed were chosen because they were co-sponsored by the provincial government (a major institution of colonization) and First Nations communities - depicting a negotiation of mobility between the settler state and First Nations.

\section{Micro Analysis}

Using Fairclough's method of critical discourse analysis, the text of the billboards was analyzed for a number of characteristics. The first level of analysis was whether the language was positive or negative. The language in the first billboard is negative: "Aint worth the risk sister." No imperative is used in the language on the first billboard, but in the second billboard, the imperative is used in the statement, "Girls don't hitchhike." The imperative case is important in that it makes a demand on behaviour or issues a command. In this case the demand on behaviour is "don't hitchhike" and targets the behaviour of hitchhikers or wouldbe hitchhikers (for more information on the imperative case, see Han 1998). The language in both cases was also analyzed for particular word choices. What stood out on the first billboard was the decision to use "aint." Other word choices that stuck out were the naming of the intended audience in both billboards: "Sister" in the first billboard and "Girls" in the second billboard. In the following section, a brief analysis of these word choices will be made.

The images within the two billboards were also read as "text" as they greatly added to the meaning/discourse housed within the billboards. The images specifically referenced the numerous cases of disappearances and murders along the Highway of Tears. The first billboard used the imagery of a number of crosses along the highway and also ghosts surrounding the hitchhiker to visually represent the deaths, while the second billboard blatantly showed the faces of missing and murdered women (Images 1 and 2). In both cases, the imagery connected death and loss to 
the written/text based message of hitchhiking. The images are emotive in that they make reference to the grief and loss of the numerous cases of missing and murdered Indigenous women. The images are meant to illustrate the tragedy of the cases- the deaths of the women who have disappeared along the highway. The images are evocative and meant to make the viewer/consumer feel a sense of loss and sadness for the disappearances. The multiple crosses in the first billboard and the multiple head shots in the second billboard both demonstrate the significant cases of violence that have been identified (Images 1 to 4). The painting in the first billboard uses an ethereal and cool colour palette without any strong, bright or cheerful tones (Images 1 and 3). This creates a sense of sadness and influences/shapes the tone of the billboard. The imagery of the painting is intentionally soft and hazy in an effort to pick up on how the deaths of these women remain somewhat obscured and forgotten. The images, in conjunction with the written text depict a powerful message of the tragedy of the cases of violence along the Highway of Tears and demonstrate how there have been a significant number of disappearances along the highway.

\section{Mezzo Analysis}

In terms of medium, both billboards are roughly the same size. The first billboard was reproduced twice and maybe again when other billboards are removed or more spots for billboards become available. The billboards are positioned on the side of the highway, located near Thornhill, Gitwangak and Moricetown, communities with large Indigenous populations. The billboards use large fonts and in both examples, "hitchhike(ing)" is written in capital letters and presented at the top of the billboards. The use of billboards and the layout of the billboards (particularly the large font and the design elements used) indicate that this medium was used in order to target passengers of vehicles and drivers in addition to would-be hitchhikers. The signs are highly visible and as a result of the design choices, the message is understood, even when passed at highway speeds.

\section{Macro Analysis: Targeting Hitchhiking as a Contentious Mobility}

A commonality across both billboards is the presence of caution/hazard signs. In the first billboard, the image of a hitchhiker's thumb, with a line through it enclosed in a circle is reminiscent of a hazard label that would be found on a product or a traffic control sign (Image 1). In the second billboard, the image of a red caution sign, with the word "caution" in it, like the first sign, indicates a hazard that must be avoided. Hazard labels 
put onus on consumers to prevent harm. The first billboard's hazard sign is clearly targeting hitchhikers and the second billboard's caution sign, positioned next to the phrase "Girls don't hitchhike" indicates that hitchhiking is dangerous and must be avoided. Both billboards also specifically name hitchhiking as a threat to the safety of women. The second billboard in particular targets hitchiking with the second line of text "killer on the loose" beneath the text "girls don't hitchhike" and the images of the missing and murdered women. This billboard content should be considered in light of the "willing victim" construction that is often applied to Indigenous women when they face violence (Razack 2015; Gilchrist 2010; Pratt 2005; and Culhane 2003). The billboard's message positions hitchhiking as a dangerous choice made by Indigenous women. The placement of the elements and the language indicates "killer on the loose" is targeting women on the basis of whether or not they hitchhike and to hitchhike would therefore make "girls" likely targets. The reference to a singular "killer" is also interesting in this billboard in that it potentially obscures how there is a systemic issue of violence against Indigenous women, not a singular unknown assailant ${ }^{1}$.

The contentious mobility of hitchiking is the principle focus of these billboards. The message that these billboards present is that hitchhiking is bad and if a woman hitchhikes she is likely to be killed. The billboard designers are reacting to the prevalence of hitchiking as a contentious mode of mobility and present the argument that choosing to hitchhike leads to being victimized. On the first billboard, the question of "Is it worth the risk?" and the subsequent response of "Aint worth the risk sister" contains a latent sense that there is a decision to hitchike made strictly on the perceived riskiness of the behaviour. This connects to the racist/sexist accounts of "lifestyle choices" of Indigenous women highlighted by Comack and Balfour (2004). However, as presented in the literature review, there are numerous constraints on mobility, particularly for Indigenous women, that leave options other than hitchhiking scarce. The billboards present an understanding of women hitchhiking as a decision based on a perceived and calculated risk and argues that the risk is far greater than women may realize and therefore hitchhiking must be avoided. As illustrated within the previous literature review, the non-conformity of Indigenous women with dominant frames of feminin-

1. The Robert Pickton case is the highest profile case of a prolific serial killer who targeted female sex trade workers and homeless women, the majority of whom were Indigenous. There have also been murders along the Highway of Tears attributed by a serial killer, incarcerated in the U.S. who is recently deceased. For more information on the Pickton case, see Garcia Del-Moral, 2011; Culhane, 2003. 
ity is exemplified within their use of hitchhiking as a contentious mobility (Gilchrist 2010; Razack 2015).

The first billboard's imagery of ghosts and crosses conjures the history of the highway's numerous deaths and disappearances. Numbers of deaths and disappearances along the highway range significantly. The RCMP cites the official number of 18 confirmed cases while Indigenous communities and advocacy organizations suggest the number is closer to 40 cases or more (Human Rights Watch 2013: 40). The imagery on the billboards indicates is that the number of murders and disappearances are considerable. The province's message in these billboards uses the images of past deaths in order to control current modes of mobility. Fear and grief are deployed in order to prevent the contentious mobility of hitchhiking.

As important to what is on these billboards is what was left off. For example, both billboards indicate the danger of hitchhiking and their argued causal link between hitchhiking and disappearance, but neither billboard offers any options for Indigenous women who may see the signs. No alternative form of mobility, no phone number for support or any suggestion for how Indigenous women can stay safe is offered or implied. The only message is don't hitchhike, because hitchhiking is bad and dangerous. The billboards in both cases are speaking to Indigenous women and arguing that they must change their mobility/behaviour. The billboards insist on not using hitchhiking, but fall short of providing alternatives or providing support for women who are in a position where hitchhiking is the only viable option. These billboards are the province's front-line efforts to stop hitchhiking and based on the content, are specifically targeting Indigenous women.

\section{Macro Analysis Findings}

\section{Gender}

In the written words and the imagery of both billboards, the message and the audience of the billboard are gendered. The painting of the female hitchhiker on the first billboard and the photographs of the missing and murdered women (Image 2) both demonstrate that these billboards are about and for women and not men. Billboard 1 uses the pronoun, "sister" to communicate with the audience to not only assign gender but in order to instill a sense of kinship or familial relation. Billboard 2 uses the pronoun, "girls." Both sister and girls can be read as invoking a sense of paternalism/familial care. The billboards do not name women, but instead 
name "girls". Although the majority of the reported victims along the Highway of Tears were fairly young, there is a potentially paternalistic element to collectively referring to women and girls together as "girls". This is important when analyzed in relation to the paternalism and infantilization inherent to the colonial project in Canada (Razack 2002; Jiwani 2010). Agger illustrates how moving away from the language of "girls" to refer to women of a variety of ages and only use "girls" for very young females was a component of post-war feminist politics of naming (2004: 124). Although, perhaps the intention was to target very young women, the use of girls is also potentially patronizing.

The targeting of female hitchhikers also can be read as holding an invisible/implied message that drivers and individuals who pick up female hitchhikers are male. This potential implied gender division between female hitchhiker and male driver further complicates the power imbalance already found between driver and hitcher in hitchhiking mobility. As described earlier, interdependence is central to hitchhiking and is also a characteristic that makes it a form of contentious mobility. These billboards, by gendering hitchhiking as a mode used by women who pick up rides from male drivers make the interdependence of the act of hitchhiking a gendered power imbalance. The province's inclusion of gender in these billboards fits into existing gender norms surrounding women's dependence on men. Although men are absent from the billboards, both as an audience and as the subjects of the boards, their absence demonstrates the gendered dimension of these billboards and further highlights how provincial responses to contentious mobility are themselves gendered.

\section{Race}

Compared to the blatant treatment of gender within these billboards, race is more slippery. The race of the hitchhikers can only be assumed through the skin tone used in the illustration on the first billboard (Image 1) and in the perceived race that the audience determines for the women on the second billboard (Image 2). The first billboard's painting of a woman with long straight dark hair and slightly darker skin tone does fit a certain conventional depiction of Indigenous women, and therefore is racially symbolic. This image captures a feminine and sympathetic representation of Indigenous women (LaRoque 1983; Grande 2004; Razack 2002). Along with the image, the language of "sister" may have raced elements to it. In the context of missing and murdered Indigenous women, "Stolen Sisters" and "Sisters in Spirit" are titles often used and associated with advocacy for the issue. By choosing the word "sister," the billboard taps into this discourse and quietly racializes the message. 
Sister also speaks to family and kinship, which linguistically produces a bridge from the victims depicted in the billboard and the intended audience of Indigenous female hitchhikers. ${ }^{2}$

The second billboard, in using the actual images of known victims depicts how the women on the billboard are similar in their identity as Indigenous. Indigenous identity is complicated, diverse and should not be reduced to a monolith, but the Indigenous women's group that cosponsored the second billboard with the province of British Columbia specifically selected women who have disappeared who are also identified as Indigenous (Image 2). Visually, the second billboard shows a relationship between race, mobility, gender and violence. The province's billboards are depicting hitchhikers as the racialized Other. This characterization demonstrates that it is Indigenous women's mobility that is risky, not colonial and racist attitudes and social inequalities that fuel violence against Indigenous women. The province, by stigmatizing and racializing hitchhiking is able to respond to significant cases of colonial and gendered violence against Indigenous women without sharing any blame for the racism and social inequality that contributes to cases of missing and murdered Indigenous women along the Highway of Tears.

\section{Stigmatization}

There are a number of potentially problematic elements to the billboards that stigmatize hitchhiking, place responsibility on hitchhikers and potentially demonize the hitchhikers themselves. One word choice that stood out in the first billboard was the word "Aint". As slang, "aint" invokes potential class/education illusions, particularly in how "aint" is used to communicate specifically to hitchhikers. The use of "aint" was deliberate, in that "It's not" would have worked just as well to communicate how hitchhiking is dangerous (Image 1). The question must be asked then of what work "aint" is doing in the overall message of the billboard. The analysis for this paper argues that "aint" reveals class and the word choice to use "aint" over other alternatives speaks to an effort to appeal to the perceived lower class status of hitchhikers. This implicit connection forged between hitchhiking and class stigmatizes hitchhiking as a contentious mobility, by making it an exclusive mobility of the lower class. This further alienates hitchhikers, particularly in how there was a deliberate word choice in the billboard to use slang to communicate to them. There are, of course, other potential readings of the word "aint" but it is important nonetheless to consider why the province would

2. Although the majority of the missing and murdered women along the Highway have been Indigenous, there have been non-Indigenous cases as well. 
use slang. The goal of this language decision is to attract the audience, whether the intent was expressly lower class or not, and to establish a familiarity with the audience consuming the messages of the billboard.

Along with the caution/hazard signs used in the presentation of hitchhiking, the imperative statement of "don't hitchhike" in Billboard 2 and the repeated word of "risk" in Billboard 1 stigmatizes hitchhiking as a bad/irresponsible behaviour (Images 1 and 2). As traffic or hazard signs are to be obeyed, the hazard/caution signs on the billboards demonstrate that to hitchhike is to be disobedient to do something wrong. This stigmatization speaks to the larger issue of how contentious mobility is constrained by the province and the Canadian government more broadly and how the movement of Indigenous peoples in particular is deliberately targeted (Razack 2015). The macro level analysis positions these billboards within existing discourses and social norms surrounding gender, class and race. This analysis demonstrates that women who hitchhike are depicted in the province's billboards as wrongdoers. The billboards, interlocking with existing social constructions of gender, race and class, depict Indigenous female hitchhikers as knowingly/willingly putting themselves in danger, which ignores the oppressions that often led to Indigenous women using hitchhiking and disregards how racism and sexism factor into the instances of violence against women on the Highway of Tears.

\section{Background on the Billboards ANd Moving Forward}

Although there are elements within the billboards that reflect potentially problematic assumptions in regards to gender, race and contentious mobility, this paper is not by any means attempting to downplay the significance of the province seeking ways to raise awareness about violence against Indigenous women along the Highway of Tears. The highway, as indicated at the beginning of this paper, has several characteristics that not only make hitchhiking a common occurrence, they also make patrolling the highway, monitoring usage of the highway and attempting to contact hitchhikers difficult. Efforts to prevent violence against Indigenous women are necessary and the billboards are a potentially useful method for the province to combat violence. However, this good intention does not render the billboards neutral or innocent of engaging in racial and gendered stereotypes of hitchhiking as a contentious mobility.

The billboards analyzed within this paper were in fact the product of a recommendation that resulted from the Missing and Murdered Women's Symposium of 2006. They were first published in late 2006 (Missing and 
Murdered Women's Symposium Report 2006). Recommendation nine of the symposium's report clearly states. "[t]hat a number of billboards, and many more posters, be placed at strategic locations along the Highway 16 corridor between Prince George and Prince Rupert, British Columbia" (2006: 23). What is notable about this recommendation follows in the more detailed summary of the recommendation. The report recommends: "carefully designed billboards will be used to generate traveling public awareness on the issue of the murdered and missing women, and also contain a 1-800 number for the public to call in tips, potential leads, or even cell phone call in the location of any female hitchhiker they encounter" (2006: 23). The recommendation calls on the creation of billboards that target "travelling public" and include a phone number to gain information, where as the resulting billboards instead targeted Indigenous women and lacked any alternatives or strategies for keeping women safe, other than avoiding hitchhiking. Again, this paper is not dismissing these billboards as potentially useful and containing excellent intentions, but the billboards do not reflect the recommendations produced in partnership with Indigenous peoples and advocates and demonstrate how gender, race and class shape the perception of hitchhiking as a contentious mobility.

Through an analysis of their content this paper demonstrates that there are potentially problematic messages being communicated in regards to Indigenous women who hitchhike in provincial sponsored billboards along the Highway of Tears. Moving forward, more research must be done in order to realize how Indigenous women who hitchhike are responding to/ impacted by this messaging and how they view these signs. As a vital but stigmatized mode of mobility, further research is needed to understand how Indigenous women engage in hitchhiking and how the frequent cases of violence impact their own perceptions of safety and mobility along the Highway.

I do not suggest that the correct course of action would be to take down these billboards and stop this attempt at keeping women safe. Instead, moving forward I suggest that the future publications of billboards must stay true to the recommendations from the missing women's symposium, with a focus on using the billboards to gain awareness and provide hitchhikers with highly visible safety resources.

\section{Conclusion}

Hitchhiking, as a discourse analysis of the billboards along the Highway of Tears demonstrates, is depicted as dangerous behaviour that should 
be completely avoided. Under no circumstance do these billboards suggest that hitchhiking is acceptable and the implicit messaging of the billboards is that hitchhiking causes women to be victimized. What is absent from these billboards is any consideration for the socio-economic reasons for hitchhiking and any possible redeeming features of hitchhiking. Furthermore, the discourse analysis reveals that women who hitchhike are always and already at least partially to blame for any violence they encounter along the highway. The billboards warn that a serial killer is bound to pick-up any hitchhiker and that the only way to avoid being murdered is to not hitchhike. This messaging and stigmatization of hitchhiking obfuscates the lasting impacts of colonialism on Indigenous women's mobility. Furthermore, these billboards and their anti-hitchhiking messaging fit into a broader narrative of the government's attempts to regulate, constrain and police the mobility of Indigenous peoples. The discourse analysis completed for this paper illustrated problematic racial and gender elements within the billboards that further subordinate the status of Indigenous women who hitchhike, rendering them social outsiders and deviants.

Hitchhiking falls outside of the privileged mode of automobility and is largely opposed by the province as dangerous. As a result, this paper presents hitchhiking as a contentious form of mobility, but a common form of mobility nonetheless. The characteristics of the Highway of Tears and the socio-economic features of Northwestern British Columbia impact what modes of mobility are accessible and used by some Indigenous women. A simple condemnation of hitchhiking as dangerous and therefore bad is a Band-Aid solution at best. Use of the contentious mobility of hitchhiking and also the subsequent responses of the province to hitchhiking are deeply rooted in colonization and its inherent constraints on Indigenous mobility. Indigenous women who hitchhike, both while engaging in this contentious mode of mobility and in the representations of hitchhiking featured in the province's billboards are locked into complex intersections of race, gender, space and mobility.

\section{REFERENCES}

Agamben, G. 1998. Homo Sacer: Sovereign Power and Bare Life. Translated by D. Heller-Roazen, Stanford: Stanford University Press.

Agger, Ben. 2004. The Virtual Self: A Contemporary Sociology. Oxford: Blackwell.

Bannerji, Himani. 1993. Returning The Gaze: Essays on Racism, Feminism and Politics. Toronto: Sister Vision Press. 
Bauman, Zygmunt. 2004. Wasted Lives: Modernity and its Outcasts. Oxford: Polity.

Benoit, Cecilia; Dena Carrol; and Munaza Chaudhry. 2003. "In Search of a Healing Place:

Aboriginal Women in Vancouver's Downtown Eastside". Social Science and Medicine. 56 (1): 821-833.

Butler, Judith. 1993. Bodies That Matter: On the Discursive Limits of Sex. New York: Routledge.

Cacho, Lisa Marie. 2012. Social Death: Racialized Rightlessness and the Criminalization of the Unprotected. New York: NYU Press.

Comack, Elizabeth and Gillian Balfour. 2004. The Power to Criminalize: Violence, Inequality and the Law. Halifax: Fernwood Publishing.

Culhane, Dara. 2003. "Their Spirits Live Within Us: Aboriginal Women Downtown Eastside Vancouver Emerging Into Visibility" The American Indian Quarterly 27(3): 593-606.

Dhamoon, Rita. 2009. Identity/ Difference Politics: How Difference is Produced and Why it Matters. Vancouver: UBC Press.

Dobrowolsky, Alexandra and Jane Jenson. 2004. "Shifting Representations of Citizenship: Canadian Politics of "Women" and "Children" Social Politics. 11(2): 154-180.

England, Jennifer. 2000. "Representation and the Production of Space: Aboriginal Women in Downtown Eastside, Vancouver" Master's Thesis. University of British Columbia, Department of Geography.

Fanon, Frantz. 1963. Wretched of the Earth. New York: Grove Press.

Farley, Melissa; Jacqueline Lynne; Ann J. Cotton. 2005. "Prostitution in Vancouver: Violence and the Colonization of First Nations Women" Transcultural Psychiatry. 42(2): 242-271.

Fiske, Jo-Anne. 2006. "Boundary Crossings: Power and Marginalization in the Formation of Canadian Aboriginal Women's Identities" Gender and Development. $14(2): 247-258$.

Garcia-Del Moral, Paulina. 2011. "Representation as a Technology of Violence: On the

Representation of the Murders and Disappearances of Aboriginal Women in Canada and Women in Ciudad Juarez. Canadian Journal of Latin American and Caribbean Studies. 36(1): 33-62.

Gilchrist, Kristen. 2010. "Newsworthy Victims? Exploring Differences in Canadian Local Press Coverage of Missing/ Murdered Aboriginal and White Women" Feminist Media Studies. 10(4): 373-390.

Gotell, Lise. 2009. "Rethinking Affirmative Consent in Canadian Sexual Assault Law: Neoliberal Sexual Subjects and Risky Women" Akron Law Review. 4(1):865-898. 
Grande, Sandy. 2004. Red Pedagogy: Native American Social and Political Thought. Lanham: Rawman and Littlefield Publishers.

Han, Chung-Hye. 1998. "The Structure and Interpretation of Imperatives: Mood and Force in Universal Grammar." Institute for Research in Cognitive Science. Thesis available online at http://repository. upenn.edu/cgi/viewcontent.cgi?article $=1076 \&$ context=ircs_reports.

Highway of Tears Recommendation Report. 2006. Available online at: http://www.turtleisland.org/healing/highwayoftears.pdf.

hooks, bell. 2000. Feminist Theory From Margin to Center. Cambridge: South End Press.

Human Rights Watch. 2013. Those Who Take Us Away. Report Published online February 2013. Accessed online March 2015 at: https://www.hrw.org/reports/2013/02/13/those-who-take-us-away-0

Hunt, Sarah. 2010. "Colonial Roots, Contemporary Risk Factors: a cautionary exploration of the domestic trafficking of Aboriginal women and girls in British Columbia, Canada" Alliance News. Accessed online at: http:// s3.amazonaws.com/academia.edu.documents/29553201/HUNT_Alliance News_July_2010.pdf?AWSAccessKeyId=AKIAJ56TQJRT WSMTNPEA\&Expires $=1452224337 \&$ Signature $=$ Xzas417PWV3NPkf XjlgyH\%2FQw0S8\%3D\&response-contentdisposition=inline $\% 3 \mathrm{~B} \% 20$ filename\%3DColonial_Roots_Contemporary_Risk_Factors.pdf.

Jiwani, Yasmin. 2009. "Symbolic and Discursive Violence in Media Representations of Aboriginal Missing and Murdered Women." Canadian Journal of Communications. 31(1): 895-917.

Jiwani, Yasmin and Mary Lynn Young. 2006. "Missing and Murdered Women:

Reproducing Marginality in News Discourse." Canadian Journal of Communication 31(11): 895-917.

LaRoque, Emma. 1983. "The Metis in English Canadian Literature." The Canadian Journal of Native Studies. 3(1): 85-94.

Lawrence, Bonita and Enakshi Dua. 2008. "Decolonizing Anti-Racism" Social Justice. 32(4): 120-144.

Kelm, Mary Ellen. 1998. Colonizing Bodies: Aboriginal Health and Healing in British Columbia 1900-1950. Vancouver: UBC Press.

Mawani, Renisa. 2002. "In Between and Out of Place." in Race, Space and the Law. Ed. Sherene Razack. Toronto: Between the Lines.

McClintock, Anne. 1995. Imperial Leather: Race, Gender and Sexuality in the Colonial Context. New York: Routledge.

McGrath, Ann and Winona Stevenson. 1996. "Gender, Race, and Policy: Aboriginal Women and the State in Canada and Australia" Labour History. 71(1): 37-53. 
Moores, Patrick. 2006. "(Re)covering the Missing Women: News Media Reporting on Vancouver's "Disappeared"”. Master's Thesis, University of British Columbia.

Packer, Jeremy. 2008. Mobility Without Mayhem: Safety, Cars, and Citizenship. Durham NC: Duke University Press.

Pratt, Geraldine. 2005. "Abandoned Women and Spaces of Exception” Antipode. The 2005 Antipode Lecture. 1053-1077.

Razack, Sherene. 1998. Looking White People in the Eye: Gender, Race, and Culture in Courtrooms and Classrooms. Toronto: University of Toronto Press.

Razack, Sherene. 2011. "Timely Deaths: Medicalizing the Deaths of Aboriginal People in Police Custody" Law Culture and the Humanities. 9(2): 352374.

Razack, Sherene. 2002. "Gendered Racial Violence and Spatialized Justice: The Murder of Pamela George" in Race, Space and the Law: Unmapping a White Settler Society. Toronto: Between the Lines.

Razack, Sherene. 2015. Dying from Improvement: Inquests and Inquiries into Indigenous Deaths in Custody. Toronto: University of Toronto Press.

Royal Canadian Mounted Police. 2014. "Missing and Murdered Aboriginal Women: A National Operational Overview." Accessed online at: http:// www.rcmp- grc.gc.ca/pubs/mmaw-faapd-eng.htm.

Sehdev, Robinder. 2012. "Beyond the Brink: Indigenous Women's Agency and the Colonisation of Knowledge in the Maid of the Mist Myth" Cultural Studies Review 18 (3): 240-262.

Sharma, Nandita and Cynthia Wright. 2008. "Decolonizing Resistance, Challenging Colonial States" Social Justice. 35(3): 120-138.

Sheller, Mimi. 2011. "Mobility" Accessed online at: Sociopedia.isa.

Sheller and Urry. 2006. “The New Mobilities Paradigm." Environment and Planning. 38(1): 207-226.

Spivak, Gayatri. 1988. "Can the Subaltern Speak?” In C. Nelson and L. Grossberg ed. Marxism and the Interpretation of Culture. Urbana IL:University of Illinois Press.

Strega, Susan; Caitlin Janzen; Jeannie Morgan; Leslie Brown; Robina Thomas and Jeannine Carriere. 2014. "Never Innocent Victim: Street Sex Workers in Canadian Print Media" Violence Against Women.

Thobani, Sunera. 2007. Exalted Subjects: Studies in the Making of Race and Nation in Canada. Toronto: University of Toronto Press.

Thrift, Nigel. 2004. "Driving in the City" Theory, Culture and Society. 21(4): 41-59.

Urry, John. 2007. Mobilities. Cambridge: Polity Press. 
Urry, John. 2004. "The "System" of Automobility" Theory, Culture and Society. 21(4): 25-39.

Urry, John. 2000. Sociology Beyond Societies: Mobilities for Twenty First Century. Florence KY: Routledge.

Vancouver Police Department. 2011. "The Tragedy of Missing and Murdered Aboriginal Women in Canada: We Can Do Better." Accessed online at: http://vancouver.ca/police/assets/pdf/reports-policies/missing-murderedaboriginal- women-canada-report.pdf

De Vries M. 2003. Missing Sarah: A Vancouver Women Remembers Her Vanished Sister. Toronto: Penguin.

Wacquaint, Loic. 2001. "Deadly Symbiosis: When Ghetto and Prison Meet and Mesh." Punishment and Society 3(1): 95-134.

Warwick, Derek. 2009. "Sexual Colonialism: Aboriginal Women and Gendered Violence" Transcending Silence. (Spring): 1-7.

Williams, Allison. 1997. "Canadian Urban Aboriginals: A Focus on Aboriginal Women in Toronto" The Canadian Journal of Native Studies 17(1): 75101.

Katherine Morton is a $\mathrm{PhD}$ candidate in the department of Sociology at Memorial University of Newfoundland. Born and raised on Vancouver Island in British Columbia, Katherine specializes in social research related to Indigenous populations and colonial violence in British Columbia. Her PhD research identifies points of intersection between mobility, violence, Indigenous identity and colonialism. She completed research in her MA on the construction of tropes of Indigenous identity and their presence in Indigenous focused public inquiries. Prior to grad school, Katherine held positions in both the federal and provincial public service researching and providing policy analysis on Indigenous cultural heritage, the duty to consult and demographic change. Her research interests include mobility, identity politics, critical theory, colonialism, land claim negotiations and discourse analysis.

E-mail: kam813@mun.ca 


\section{ApPendix 1: Billboard ImageS}

\section{Image 1: Billboard 1}

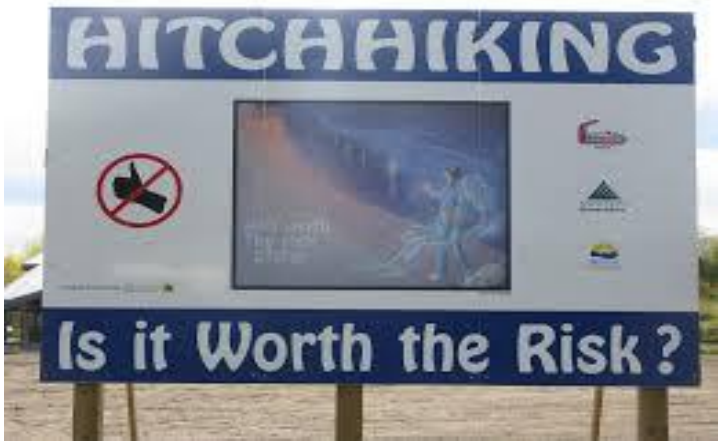

Photograph credit: Public Domain Image Accessed via: https://www.flickr.com/photos/tiredofit/4589464887credited to photographer David Conroy

Image 2: Billboard 2

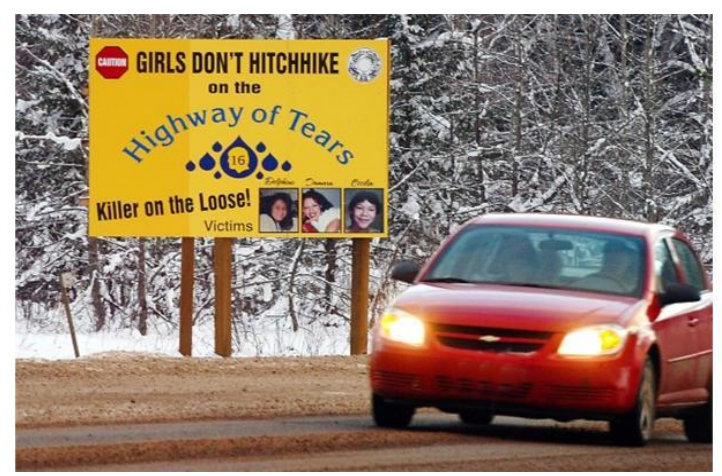

Photograph credit: Steve Bosch, Vancouver Sun. Available online at http://www.vancouversun.com/Film+shines+light+forgotten+Highway+Tears+wo men/10842712/story.html?_lsa=e88a-c212 
Image 3: Detail on Billboard 1

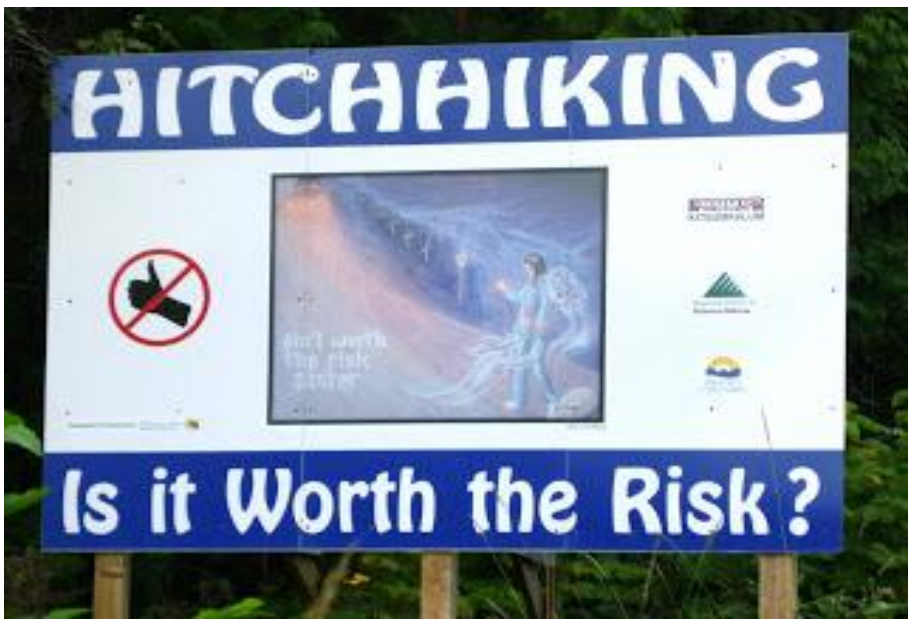

Photograph Credit: http://outlawsandoutcasts.blogspot.ca/2012/11/highway-oftears-tv.html Bob Friel, 2012.

Image 4: Detail on Billboard 2

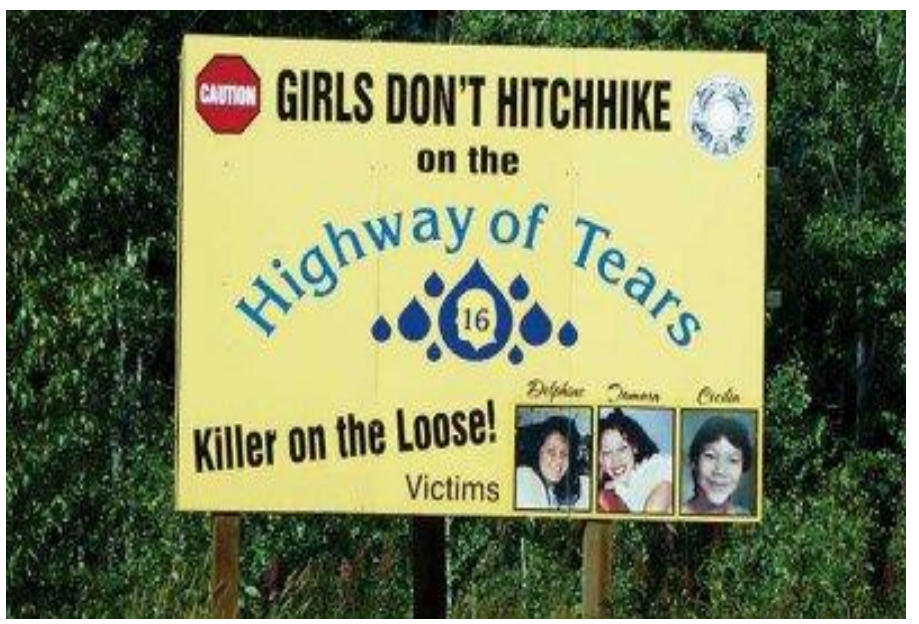

Photograph Credit: http://www.outsideonline.com/1900566/vanishing Bob Friel, 2012. 


\section{Appendix 2: Map of the Highway of Tears (Highway 16) ANd}

\section{LOCATION OF BILLBOARDS}

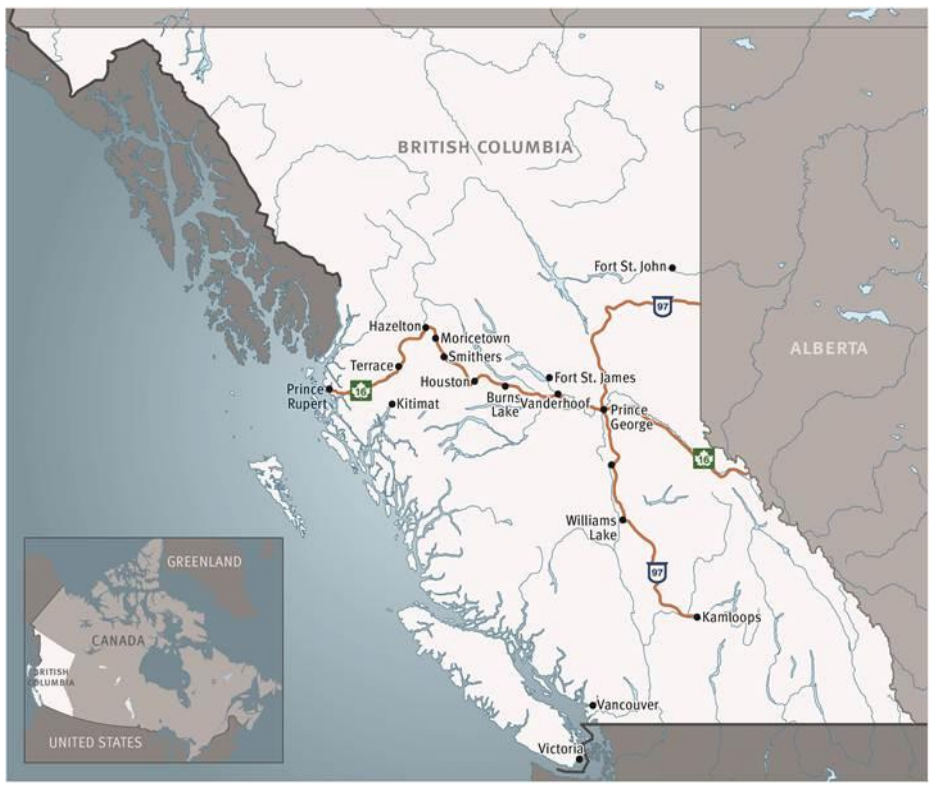

Map Credit: Human Rights Watch, 2013. N.B. Billboards located at Thornhill (overlapping with where Terrace is indicated on this map), Moricetown and Gitwangak (81 kilometers East of Moricetown, too small to be indicated on this map) 
Appendix 3: Map of the Highway of Tears (Highway 16)

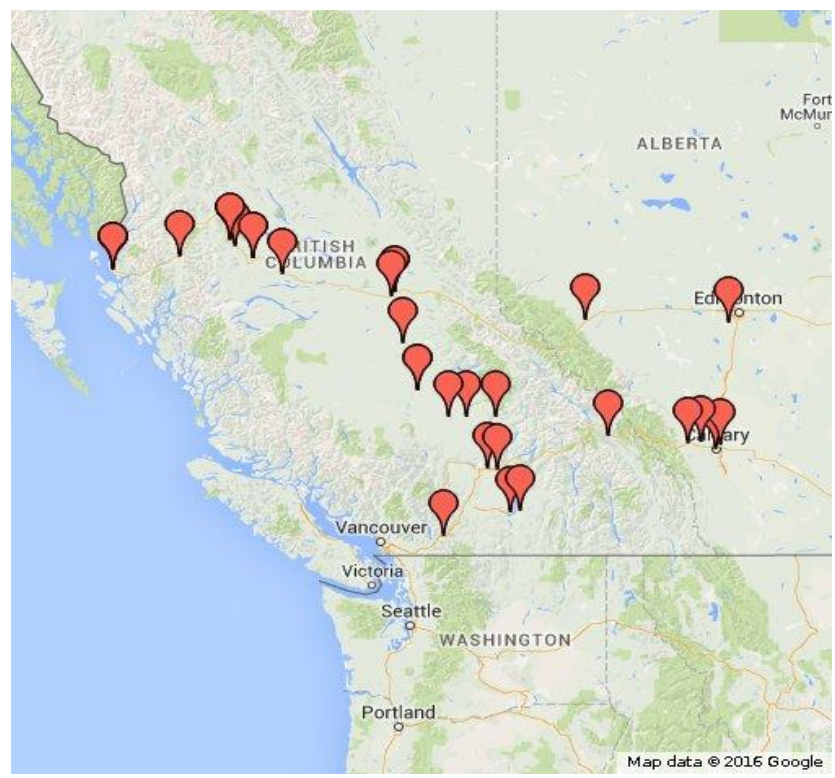

Photo Credit: Google Maps, 2016 "Highway of Tears"

https://www.google.com/maps/d/viewer?mid=zLD5QMA14wWw.kK_POvwvqrfw\&1 N.B. Points on the map indicate investigated disappearances and their location. 
326 C Canadian Journal of Sociology/Cahiers Canadiens de sociologie 41(3) 2016 